\title{
The Common Foreign and Security Policy
}

Citation for published version (APA):

Dijkstra, H., \& Vanhoonacker - Kormoss, S. (2017). The Common Foreign and Security Policy. Oxford Research Encyclopedia of Politics. https://doi.org/10.1093/acrefore/9780190228637.013.155

Document status and date:

Published: 01/01/2017

DOI:

10.1093/acrefore/9780190228637.013.155

Document Version:

Publisher's PDF, also known as Version of record

Document license:

Taverne

\section{Please check the document version of this publication:}

- A submitted manuscript is the version of the article upon submission and before peer-review. There can be important differences between the submitted version and the official published version of record.

People interested in the research are advised to contact the author for the final version of the publication, or visit the DOI to the publisher's website.

- The final author version and the galley proof are versions of the publication after peer review.

- The final published version features the final layout of the paper including the volume, issue and page numbers.

Link to publication

\footnotetext{
General rights rights.

- You may freely distribute the URL identifying the publication in the public portal. please follow below link for the End User Agreement:

www.umlib.nl/taverne-license

Take down policy

If you believe that this document breaches copyright please contact us at:

repository@maastrichtuniversity.nl

providing details and we will investigate your claim.
}

Copyright and moral rights for the publications made accessible in the public portal are retained by the authors and/or other copyright owners and it is a condition of accessing publications that users recognise and abide by the legal requirements associated with these

- Users may download and print one copy of any publication from the public portal for the purpose of private study or research.

- You may not further distribute the material or use it for any profit-making activity or commercial gain

If the publication is distributed under the terms of Article $25 \mathrm{fa}$ of the Dutch Copyright Act, indicated by the "Taverne" license above, 


\section{The Common Foreign and Security Policy FREE}

Hylke Dijkstra, Department of Political Science, Maastricht University

and Sophie Vanhoonacker, Department of Political Science, Maastricht University

https://doi.org/10.1093/acrefore/9780190228637.013.155

Published online: 25 January 2017

\section{Summary}

The member states of the European Union (EU) coordinate, define, and implement foreign policy in the context of the Common Foreign and Security Policy (CFSP). This policy area, often referred to as EU foreign policy, has a broad scope covering all areas of foreign policy and all questions relating to security and defense. The CFSP is supported by a unique institutional framework, in which member states diplomats and officials from the EU institutions jointly make policy. It is led by the High Representative, who is the "face and voice" of EU foreign policy, and supported by the substantial European External Action Service and 140 EU delegations in other countries and international organizations.

Because foreign policy is normally the business of sovereign states, the exceptional nature of the CFSP has long been a subject of inquiry. The CFSP has particularly puzzled advocates of the traditional theories of European integration and international relations, who have failed to appreciate what the EU does in the field of high politics. Given the absence of formal diplomatic recognition and a strong reliance on the resources of the member states, the EU is still not a full-fledged actor, yet it has a strong international presence nonetheless. Its presence and the gradual increase in "actorness" have also raised questions about whether the EU presents a different type of actor, a civilian or normative power, which derives its influence from non-traditional sources of power.

Under the assumption that the EU has some actorness, the Europeanization of foreign policy has become an area of interest. Member states can act through the EU structure to achieve more impact internationally, can adjust national foreign policy on the basis of EU positions, and are socialized into greater European coordination. The relationship between national and EU foreign policy is thus a significant topic of debate. Finally, governance perspectives increasingly provide insight into the organization of the CFSP. How the member states and the EU institutions collectively coordinate, define, and implement EU foreign policy is not only an important question in itself but also matters for policy outcomes.

Keywords: European Union politics, foreign policy, CFSP, international actor, external identity, Europeanization, governance, High Representative, EEAS, Brusselization 


\section{Introduction}

The member states of the European Union (EU) coordinate, define, and implement foreign policy in the context of the Common Foreign and Security Policy (CFSP). This policy areaoften referred to as EU foreign policy-has a broad scope. It covers all areas of foreign policy, including all questions relating to security and defense (see, on the Common Security and Defence Policy, Duke, 2016_http://politics.oxfordre.com/view/10.1093/acrefore/

9780190228637.001.0001/acrefore-9780190228637-e-156>). Other EU external policies, such as trade, development cooperation, and humanitarian assistance, fall outside its scope. The CFSP was established by the Treaty of Maastricht in 1993. It succeeded European Political Cooperation (EPC), through which the member states had coordinated their foreign policies since the 1970s. The CFSP is supported by a distinctive institutional framework, in which national diplomats and EU officials jointly make policy on the basis of consensus. It is led by the High Representative, who is the "face and voice" of EU foreign policy, ${ }^{1}$ and supported by the Brussels-based European External Action Service (EEAS) and around 140 EU delegations in third countries and international organizations.

Because foreign policy is normally the business of sovereign states, the exceptional nature of the CFSP has long been a subject of inquiry (for introductions, see Jørgensen, Aarstad, Drieskens, Laatikainen, \& Tonra, 2015; Hill \& Smith, 2011; Keukeleire \& Delreux, 2014; Smith, 2014). The CFSP has particularly puzzled advocates of the traditional theories of international relations and European integration, who have difficulty explaining what the EU does in foreign policy. The ambiguity in foreign diplomatic recognition and a reliance on the resources of its member states makes the EU an unconventional international actor. Yet the EU has developed a strong international presence nonetheless. This also raises questions about the EU's international identity. Does the EU present a different type of actor-a civilian or normative power-which derives its influence from non-traditional sources of power? Or is the EU, as sovereign states, driven by material interests?

The relations between EU and national foreign policy are critically important. The member states can act through the EU to achieve more impact internationally. At the same time, the CFSP puts pressure on the member states to adjust their national foreign policies. While EU foreign policy often complements national foreign policy, it can also replace and challenge national efforts. This raises questions of coherence. Finally, it is relevant to pay attention to the governance of EU foreign policy. The unique method of policymaking, through which member states and the EU institutions coordinate, define, and implement the CFSP, affects policy outcomes. As such, the machinery behind EU foreign policy is instrumental to understanding the role of the EU as an international actor and its relations with national foreign policy.

This article starts off by conceptualizing the EU as an actor in diplomatic and international affairs. It continues with the relations between EU and national foreign policy. It finally analyzes the governance of EU foreign policy. The conclusion reflects on the status of CFSP research. This article focuses on key academic debates and does not seek to summarize the numerous studies on EU foreign policy toward particular regions and countries. 


\section{The EU as an International Actor}

The starting point when studying EU foreign policy is to conceptualize the EU as an international actor. The domain of international relations is normally reserved for sovereign states. As a non-state actor, the EU is not automatically recognized by the other states, it cannot join all international organizations, and it has had difficulty participating in negotiations. A key question for scholars has thus been whether, in fact, the EU is an international actor. And if the EU can be considered an actor, what type of actor is it? What are its ends and means? Before going to these questions, it is important to provide some background on EU foreign policy.

EU foreign policy has a long history. After the European Defence Community (EDC) failed ratification in the French Parliament in 1954 and following the rejection of the Fouchet Plans in the early 1960s, the member states established EPC in 1970. It was a modest attempt at foreign policy coordination. EPC was initially kept separate from economic integration in the context of the European Community. Foreign ministers and national diplomats would occasionally meet to exchange information on issues of international politics and work toward a harmonization of views and joint action whenever feasible and desirable. The frequency of these meetings and the scope of the agenda increased over time. The process also became institutionalized (Nuttall, 1992; Smith, 2004). Yet EPC remained an informal intergovernmental debating club until the creation of the CFSP with the Treaty of Maastricht in 1993.

Explaining the relative absence of the EU in the area of foreign policy was not difficult. Hoffmann (1966), for example, distinguished between "low" and "high" politics when discussing the European project. Economic integration was perhaps achievable, but cooperation in foreign and security affairs was a different ball game. Waltz $(1979$, p. 152) pointed at the primacy of the member states. The member states rather than "Western Europe as any kind of a power," he noted, had responded to the Yom Kippur War in 1973, albeit "behaving at once like hens and ostriches." Also Bull (1982, p. 151) was skeptical about the prospects of European integration in foreign policy: "Europe' is not an actor in international affairs, and does not seem likely to become one; the Europe with which I am concerned is the actual one of state governments."

While the theorists of international relations and European integration could thus account for the slow pace with which EPC developed, they were much less capable of making sense of what EU foreign policy was actually about. This resulted in a new approach. Rather than defining actors along the lines of the characteristics of states, several scholars tried to come up with innovative criteria of "actorness." Sjöstedt (1977, p. 66), for example, stated that "if [Europe] is capable of behaving as an actor it must be considered as such." To have actor capability would require Europe to stand out as a separate unit in the system from its member states (Sjöstedt, 1977). After defining such new criteria, scholars could assess to what extent Europe was an actor in international politics.

Based on these ideas, Jupille and Caporaso (1998) proposed a much-used operationalization of EU actorness. The EU requires recognition by being a member of international organizations or a party to international negotiations. It needs to have the authority to act internationally by having legal competences to represent the member states. Through distinctive and 
independent institutions, it acquires autonomy from its member states. It needs to have cohesion in terms of its goals, tactics, procedures, and output. Fulfilling these criteria presents a challenge for the EU, particularly in the area of the CFSP. Yet the point was to have a yardstick to measure the degree of EU actorness across policy areas, regions, and time.

When EPC was rebranded into the CFSP in 1993, it was widely accepted that while the EU was perhaps not a full-fledged actor, it had a considerable "presence" (Allen \& Smith, 1990) in international affairs. Following the end of the Cold War and the dissolution of the Soviet Union in 1991, the EU continued to increase its mark on foreign policy. While its response to the civil wars in former Yugoslavia was hardly impressive, the post-Cold War era was more conducive of the EU playing a role in world politics. EU foreign policy was also strengthened through the establishment of new institutions such as the High Representative in 1999. The debate was therefore temporarily settled and moved to the question what type of actor the EU actually is.

The EU had traditionally been considered a "civilian power," which was "long on economic power and relatively short on armed force" (Duchêne, 1973, p. 19). Through its trade and development policies, it was able to transform its economic weight into political objectives. The use of sanctions, which have become a favorite foreign policy tool of the EU, is another example. Attaching strings to development assistance is third one. A civilian power further prioritizes settling international disputes through diplomatic means and attaches importance to international law. The notion of civilian power neatly fitted the bill with Europe lacking real military might. It was, however, not uncontroversial. Bull (1982), for instance, called civilian power a "contradiction in terms." He pointed at the need for military power following the escalation of the Cold War in the early 1980s.

The idea of civilian power, nonetheless, served as a stepping stone for the "EU as a power" debate of the 2000s. Manners (2002, p. 239) influentially argues that we should analyze not only the EU's ability to make use of civilian and military instruments but also its ability to shape conceptions of what is considered "normal" in international relations. From fundamental human rights to stable institutions, the EU has been trying to portray its norms on the rest of the world. The Normative Power Europe thesis holds that it does so successfully. For Manners (2002, p. 253) the ability to get others to accept one's norms is "the greatest power of all." The work of Manners (2002) has resulted in a cottage industry of Normative Power Europe-related research. Scholars have developed the concept and studied it empirically across cases. Other scholars have proposed other adjectives, such as ethical power (Aggestam, 2008), structural power (Keukeleire, 2003), and market power (Damro, 2012). Several have contested the concept arguing that the EU is a normal or realist power and behaves like any other state (Hyde-Price, 2006; see also Duke, 2016).

Given the prominence of the Normative Power Europe thesis, it is important to also mention different critiques. First, some argue that the EU is hardly alone as a normative power. The United States, after all, equally promotes democracy and human rights (Sjursen, 2006, p. 240; or consider Normative Power China; Kavalski, 2013). Manners (2002, p. 242) counters by noting how the EU is "different to pre-existing political forms" as a result of its historical context, hybrid forms of governance, and legal constitution. He argues that because the EU has helped former archenemies to "domesticate" their relations (p. 236), it promotes similar norms - such as peace, liberty, democracy, rule of law, and human rights-in the international arena. A second critique concerns the legitimacy of EU norms, which Manners (2002) seems 
to take for granted. Sjursen (2006, pp. 241-242) notes that the line between the EU acting as a "force for the good" and "Eurocentric imperialism" is, in fact, razor thin. Bickerton (2011) similarly points at the arbitrary nature of the EU's core values.

Perhaps the most potent critique is that Normative Power Europe can be seen as a product of its time (Bickerton, 2011, pp. 76-77). The debate coincided with the U.S. invasion in Iraq in 2003, which resulted in significant transatlantic tensions. It became fashionable in Brussels to portray the EU as advancing respectable norms with support for international law. This rhetoric was uncritically used by Normative Power Europe advocates as evidence of their thesis (Hyde-Price, 2006, p. 218; Sjursen, 2006, p. 235). Furthermore, the 1990s and 2000s were the Golden Age of European integration. Through enlargement, the EU promoted its norms in candidate countries. In global governance it had a prominent voice in discussions such as climate change. The litmus test of Normative Power Europe has, however, always been whether big powers, such as the United States and China, conform to EU norms. As we move further into the 21st century, this is becoming increasingly less likely. The Normative Power Europe thesis is thus losing some of its original appeal. Publications on realist and market power have provided balance (Damro, 2012; Hyde-Price, 2006).

The debate on what type of actor the EU represents continues to date. Scholars still discuss to what extent the EU is an actor and, if so, what its external identity is (e.g., da Conceição-Heldt \& Meunier, 2014; Nicolaïdis \& Whitman, 2013). The changing international order, in which the emerging powers increasingly compete for influence, presents furthermore a new challenge for EU as an international actor. It forces the EU to rethink the role of norms and interests in its foreign policy. The EU Global Strategy seems a step in this direction (European External Action Service, 2016, pp. 13-16). Many emerging powers also attach importance to sovereignty, which naturally complicates the life of the EU as an unconventional international actor. Research on the EU as an international actor will therefore remain important in the years to come.

\section{The EU and National Foreign Policy}

If the EU can be conceptualized to a certain degree as an international actor, this immediately triggers the question of how EU foreign policy relates to national foreign policy. After all, for the EU to be an actor requires a degree of autonomy from its member states. It should be considered a separate unit in the international system. Under the label of Europeanization theory, scholars have debated the interaction between EU-level foreign policy and nationallevel foreign policy. What also needs to be clarified is whether EU foreign policy complements, replaces, or competes with national foreign policy.

Scholars started to use the concept of Europeanization in the 1990s to examine the impact of European integration on the member states (authoritative volumes include Featherstone \& Radaelli, 2003; Vink \& Graziano, 2006). Many focused on traditional EU regulatory policies, such as the transport, cohesion, and environmental policies, which needed to be implemented nationally. One of the first scholars to apply the idea of Europeanization to the CFSP was Tonra (2001) in his study of the Dutch, Danish, and Irish foreign policy. Although the effects of Europeanization are considered to be weaker in foreign policy than in regulatory policy, the concept has proved useful in analyzing the relations between EU and national foreign policy. 
Interaction is typically considered a two-way street. Member states try to use EU foreign policy to pursue their own interests. Yet, at the same time, they are also subject to European demands.

One reason for the member states to participate in EU foreign policy is to reach "politics of scale" (Ginsberg, 1989). Most member states have limited capacities and difficulty achieving international impact. Rather than pursuing unilateral foreign policy, they may decide to act through the EU structures. The EU not only often gives the member states more leverage, it also protects them when dealing with the great powers. Rather than addressing Russia themselves, for example, the Baltic states much prefer to go through Brussels. Also, when it comes to discussing human rights with China, member states tend to voice their concerns through the EU rather than national channels of diplomacy. One way of looking at EU foreign policy is thus as a continuation of national foreign policy through different channels.

Scholars working in the Europeanization tradition analyze to what extent the member states are successful in projecting their national interests to the EU level (Wong, 2011). The use of the EU foreign policy as an "influence multiplier" (Wong, 2011, p. 158) plays out in different ways. For French President De Gaulle, for example, the very essence of Europe becoming a "third power" during the Cold War was about France continuing its influence in world affairs. On a more micro level, Belgium may seek to affect EU policies on the Democratic Republic of Congo. The idea of national projection is uncontroversial in the academic literature. It is well known that member states act through international institutions when it suits them. EU foreign policy is not different.

A more contested proposition is whether we also see a Europeanization of national foreign policy, that is, whether member states have adapted their national foreign policies as a result of EU membership and participation in EU foreign policy. When examining national adaptation processes, we can distinguish between changes in terms of norms and identity, procedures, and substance. It is worth discussing these separately. Through participating in the formulation and conduct of EU foreign policy, foreign ministers and national diplomats familiarize themselves with EU policies as well as the practices and interests of other member states. This is likely to affect their perceptions and foreign policy identities (Alecu de Flers \& Müller, 2013; Manners \& Whitman, 2000, pp. 249-252; Tonra, 2001; Wong \& Hill, 2011, p. 210). Socialization between elites does not mean that they immediately discard national interests, but they may develop a better understanding of the other member states and internalize European norms of behavior and thinking.

Participation in the CFSP has also resulted in new institutional structures. Member states have whole teams of diplomats in Brussels and in the national capitals dealing with EU foreign policy (Cross, 2011; Juncos \& Pomorska, 2011; Manners \& Whitman, 2000, p. 257). This is significant. Pomorska (2007), for instance, shows that the participation in the CFSP has been a driver for modernization for the Polish foreign ministry since it joined the EU in 2004. Finally, we can identify a Europeanization of the substance of national foreign policy. In a comparative study of 10 different member states, Wong and Hill (2011, pp. 210-215) find that the foreign policies of all member states, even the most reluctant ones, have been affected by Europeanization. They refer, for example, to the neutral member states that had to rethink their foreign policies. Participation in the CFSP has furthermore increased the scope of 
national foreign policy. Spain, for instance, suddenly had to worry about the Western Balkans. At the same time, Wong and Hill (2011 p. 216) also show that countries set limits as to how far they want to go.

The picture that Europeanization scholars offer us is, at best, mixed. There is clear evidence that national foreign policy is affected by EU foreign policy. The impact of Europeanization varies, however, across member states and subject areas. It is clear that the Europeanization of national foreign policy is not a linear process of ever increasing convergence (Musu, 2003; Wong \& Hill, 2011, p. 218). The direction of national foreign policy is shaped by European integration, but also by many other factors, which makes it difficult to come to definite conclusions.

The concept of Europeanization helps us to understand the interaction between national and EU foreign policy. Yet it is equally important to consider the positioning of EU foreign policy versus national foreign policy. Does it replace, complement, or compete with the national foreign policies of the member states? While this question is not often explicitly asked, it is implicit in much of the analysis and policy practice of EU foreign policy. It is furthermore significant when thinking about the coherence between what Brussels says and what national capitals do (Gebhard, 2011; Nuttall, 2000).

Few people would claim that EU foreign policy is completely replacing national foreign policy, but this should not prevent us from discussing it as a theoretical possibility. In federalist countries, for example, foreign policy and defense are often exclusively organized at the federal level. This provided a model for European federalists in the 1950s, who proposed the plans for the doomed EDC (Burgess, 2009, pp. 31-32). More recently, the European Constitution of 2004, which failed ratification, replaced the High Representative by no less than a EU foreign minister (Norman, 2003). This symbolic title along federalist lines would have given the officeholder some clout. Even after this ambitious title was scrapped in Lisbon Treaty of 2007, some member states still felt the need to include a declaration stating that the CFSP "will not affect the existing legal basis, responsibilities, and powers of each Member State in relation to the formulation and conduct of its foreign policy" (TFEU: Declaration 14). They were worried about the possibility of EU foreign policy superseding national foreign policy.

When going beyond these abstract "constitutional" debates and looking at the daily practice, it is clear that EU foreign policy largely complements national foreign policy. EU foreign policy has given the member states a forum to exchange information and views and to coordinate their national positions to achieve a greater impact internationally. The High Representative, the EEAS, and the approximately 140 EU delegations also largely perform complementary functions (see also next section). Foreign ministers may not have the ambition to sit through a dozen mediation meetings between Serbia and Kosovo, which makes the involvement of the High Representative useful. The EU delegations across the world have also tried to avoid competing with national embassies and rather attempt to complement their work (Balfour \& Raik, 2013, p. 33).

That having been said, it is not difficult to find examples in which EU institutions have competed with national actors for external representation, visibility, and access. The bureaucratic politics literature indeed underlines the need for the High Representative and the EEAS to justify themselves, which might result in term stepping on the "turf" of the 
member states (Adler-Nissen, 2014; Dijkstra, 2011). Equally important is the possibility that member states might ignore the objectives of EU foreign policy when they interact bilaterally with third states and international organizations. This raises the all-important question of coherence between EU and national foreign policy (Gebhard, 2011; Nuttall, 2000). Despite the efforts by Brussels and the national capitals to sing from the same hymn sheet, foreign counterparts still often must listen to contradictory voices. The CFSP is a policy area in which the member states are keen to remain in charge.

\section{The Governance of EU Foreign Policy}

A final topic concerns the governance of EU foreign policy: How have the member states and the EU institutions organized policymaking? The CFSP is often said to be an intergovernmental policy where consensus rules and the member states are omnipotent. Yet in reality the EU is multi-layered with a maze-like system of institutions. This also goes for the CFSP, where authority is dispersed across different levels and actors. Actions in the CFSP are also often linked to other policy areas, such as trade and development, which are subject to different decision-making procedures. The question of governance is closely related to the discussion of the EU as an international actor. After all, the actorness of the EU largely depend on how the internal machinery and external representation are organized. It also speaks to Europeanization and the interaction between EU and national foreign policy. Governance structures affect how national policies are projected and how adaptation and socialization take place.

The relevance of studying the governance of EU foreign policy mirrors a development in the study of the EU more widely. The process of European integration had long been analyzed through the perspective of international relations and international organization. Since the mid-1990s, however, scholars have started to borrow concepts and theories from comparative politics and public administration (e.g., Hix, 1994). The CFSP, albeit with a delay of about a decade, became an interesting laboratory for these kinds of theories as well. This development also brought about an interest in the EU's bureaucratic organization (Bauer \& Trondal, 2015). Rather than focusing on the foreign ministers, who take the formal decisions in EU foreign policy, scholars increasingly pay attention to the civil servants (Duke \& Vanhoonacker, 2006).

The organization of EU foreign policy is also a recurring theme on the day-to-day agenda of the member states. From the EPC arrangements, which relied heavily on the rotating presidency, to the negotiations over the organization of the EEAS, member states at times seem more concerned with their institutions than with producing actual output. When analyzing the governance of EU foreign policy, two issues can be studied. First the coordination between the member states. As EU foreign policy has grown increasingly intensive and wider in scope, the member states have sought to improve the efficiency of their own coordination processes. Second the delegation of functions to the EU institutions. To further increase coherence, efficiency, and impact, the member states have tasked the EU institutions with the formulation and implementation of EU foreign policy. 
The first set of governance questions involves the coordination process between the member states themselves. As EPC started modestly in 1970, the member states established a light coordination mechanism. Each six-monthly rotating presidency would organize one ministerial meeting and two meetings of political directors in its own capital. The number of EPC meetings, however, increased quickly, and the member states established a system of information-sharing to allow for continuous consultation. They also adopted rules of procedure and norms, started to coordinate in international organizations and third countries, and improved coordination between presidencies. Decisions were taken by consensus, and the European Commission was kept at arm's length. Its role was limited to coordinating between EPC and the other policies of the European Communities to achieve coherence. The rotating presidency was mandated to represent the member states internationally. As foreign policy cooperation became more prominent, the member states institutionalized their cooperation (Nuttall, 1992; Smith, 2004).

In a parallel development, the member states gradually moved foreign policy coordination from the national capitals to Brussels. This process of centralization, or "Brusselization," started when EPC was allocated some office space with the Single European Act of 1987 (Allen, 1998). Initially, only the working groups of the lower-level diplomats were based in Brussels. The foreign ministers continued to meet in the capital of the presidency-in-office. But as time passed by almost all formal meetings were moved to Brussels. With the establishment of the function of a High Representative for the CFSP in 1999, Brussels became the administrative center of EU foreign policy (Duke \& Vanhoonacker, 2006).

The institutionalization and Brusselization of EU foreign policy are important as they raise questions as to whether the national capitals are losing their sovereign control over foreign policy. At minimum, it can be observed that EU foreign policy is no longer a purely intergovernmental policy area in which national leaders meet to discuss world affairs on an ad hoc basis without any commitment. The mode of governance can be better described as "intensive transgovernmentalism" (Wallace \& Reh, 2015, pp. 109-111; see also "new intergovernmentalism" in Bickerton, Hodson, \& Puetter 2015). Much of the decision-making remains in the hands of key national officials, but they meet on a continuously rather than ad hoc basis. The traditional EU institutions play a marginal role, but the member states have made special institutional arrangements, such as the establishment of the EEAS, to facilitate their work.

Various scholars have studied the effects of institutionalization and Brusselization on the attitudes and identities of national diplomats engaged in EU foreign policy. Already in 1973, the member states themselves talked about a "coordination reflex," in which diplomats first looked at their European partners before reacting to world events (also Nuttall, 1992). With the development of the CFSP, the socialization of European diplomats and their esprit de corps within the different committees became a topic of academic debate (Cross, 2011; Juncos \& Pomorska, 2011). The argument is that since these diplomats meet so frequently, they start to adopt new role conceptions that affect their identity and loyalties. They identify with EU foreign policy and want to make the system work. Rather than pushing national interests until the very end, they try to solve problems and accommodate the other member states. It is important, however, not to overstate this argument. The diplomatic profession is about socialization and troubleshooting, but diplomats are aware of the red lines in their instructions. 
The second set of governance questions is about why, and to what extent, the member states have delegated functions to the EU institutions (Dijkstra, 2013; Wagner, 2003). The member states relied for several decades on the services of the rotating presidency. This had the distinct advantage of keeping the sensitive foreign policy tasks in-house. By not involving the EU institutions in the foreign policy discussions, the member states felt they could keep more control. The EU institutions have nonetheless carved out a role for themselves. Linkages between the CFSP and other external relations policies have allowed the European Commission and even the European Parliament and the European Court of Justice some influence. Furthermore, since the Treaty of Amsterdam in 1999, the member states have delegated several tasks in the area of foreign policy to the de novo EU institutions, such as the Council and the EEAS. These EU institutions are permanent, whereas the rotating presidency had a temporary character. Continuation and the need for professionalism were considered critical when engaging in longer-term diplomatic relations or sending out soldiers on military operations.

While the member states have long tried to keep the European Commission out of the CFSP, it was clear from the beginning that foreign policy could not be kept entirely separate from the other fields of external relations, such as trade, development, and enlargement policy. To guarantee the coherence of EU external relations, the Commission was allowed a way in (Nuttall, 1992, 2000; Smith, 2004). The case of sanctions provides an example. While sanctions are part of foreign policy, they must be implemented through trade policy, where the Commission traditionally has a strong role. From the establishment of EPC to the Treaty of Lisbon, the Commission has tried to get more involved in the CFSP using the argument of coherence (Dijkstra, 2014; Spence, 2016). Similarly, the European Parliament has increased its profile. Using some of its powers, such as its say over the budget, its right to elect EU commissioners, or its job to ask questions, it has forced the member states to take it more seriously. Finally, while it does not have a formal role in the CFSP, the European Court of Justice has made rulings on several issues that touch upon foreign policy.

More important than the role of the traditional EU institutions has been the delegation of tasks to so-called de novo EU institutions (Bickerton, Hodson, \& Puetter, 2015). The establishment of the post of High Representative for the CFSP in the Amsterdam Treaty in particular proved a sea change for the governance of EU foreign policy. While the High Representative formally assisted the rotating presidency, the first officeholder Javier Solana was an experienced politician, who quickly put many national foreign ministers in the shadows (Müller-Brandeck-Bocquet \& Rüger, 2011). He was also given a policy staff, which grew during his 10-year tenure. With the Lisbon Treaty of 2009, the post of High Representative was significantly upgraded. It incorporated all the foreign policy functions of the rotating presidency. For example, the High Representative is now the permanent chair of the Foreign Affairs Council. In addition, the High Representative became part of the European Commission and serves as a vice president in the College of Commissioners. This gives the High Representative the possibility to work more closely together with the commissioners responsible for the other external relations policies. The member states furthermore created the EEAS in 2011 by merging all the EU offices dealing with foreign policy and complementing them with national diplomats. As a result, the EU has now a serious diplomatic service, which also includes some 140 EU delegations around the world (Balfour \& Raik, 2013; Batora \& Spence, 2015; Smith, Keukeleire, \& Vanhoonacker, 2016). 
Even more than the institutionalization and Brusselization of coordination, the delegation of foreign policy tasks to the EU institutions raises questions about the erosion of sovereignty. Do the member states still control EU foreign policy? The academic answer is a qualified yes (Dijkstra, 2013). While the EU institutions have influenced several specific instances of foreign policy and have some organizational autonomy (Henökl \& Trondal, 2015), it is worth pointing out that the High Representative and the EEAS remain relatively weak actors. They play a role in the formulation and implementation of EU foreign policy, but the final decisions are still taken by the member states. The member states have also gone out of their way to establish control over the EEAS. Indeed, the whole point of de novo bodies, such as the EEAS, is to keep foreign policy out of the powerful European Commission. In addition, it is also worth pointing out that while the EEAS resources are impressive, the total staff is similar only to that of a medium-sized national diplomatic service.

Weak leadership is also part of the reason why the EEAS has not exploited its full potential (Vanhoonacker \& Pomorska, 2013). Although she had more powers and resources, former High Representative Catherine Ashton has been less entrepreneurial than her predecessor Solana. When she did get personally involved, it was often not controversial. Ashton did useful work rather than challenging the member states. It appears that current High Representative Federica Mogherini, who assumed office in November 2014, exerts more leadership than Ashton. She has higher visibility and has been praised for concluding the negotiations with Iran concerning nuclear non-proliferation. She has furthermore been the driving force behind the EU Global Strategy. Yet Mogherini has also been careful to complement the member states rather than to undermine them.

The governance of EU foreign policy has been extensively researched. While the parallel processes of institutionalization, Brusselization and delegation have given EU foreign policy some autonomy from its member states, it is not fully autonomous. Rather, EU foreign policy is uniquely organized as a machinery in which the member states and the EU institutions jointly make policy. It is no longer an ad hoc circus that travels across Europe every sixmonths as a result of the changing presidency. It is continuous and permanent-and transgovernmental rather than intergovernmental. The strength of EU foreign policy, nevertheless, still depends largely on the input of the member states.

\section{Conclusion}

The Maastricht Treaty, which entered into force in 1993, established the CFSP. This policy area has been further developed by the member states ever since. The CFSP has also received widespread attention from the scholarly community. It has sparked a range of new questions and puzzles for students of European integration. It has encouraged academics to experiment with different approaches ranging from international relations to comparative politics, foreign policy analysis, and public administration.

The EU's actorness and its identity have been topic of debate. It is far from evident that the EU, like sovereign states, has the "capacity to behave actively and deliberately in relation to other actors in the international system" (Sjöstedt, 1977, p. 16). In addition, it is debatable whether the EU pursues similar ends and means as sovereign states. An influential conceptualization has been that of the EU as a normative power (Manners, 2002)-the 
argument goes that the EU is seeking to transform the norms and standards of world politics. While the concept has been criticized, it nicely illustrates how scholars struggle to make sense of an active unconventional international player.

A second key debate concerns the relations between EU and national foreign policy. If the EU has indeed some actorness, it is important to know where it stands in comparison to the foreign policies of the member states. The Europeanization debate, which started in the early 2000s, has been most helpful. It has clarified the interaction between EU and national foreign policy. It has also resulted in many country studies exploring the impact of Europeanization. Although it is clear that member states continue to jealously guard their control over foreign policy, all of them, including the larger member states, accept the EU as a frame of reference. EU foreign policy constrains national foreign policy choices. Equally important is that EU foreign policy increasingly not only complements national foreign policy but also sometimes replaces and competes with it.

The third debate is about the governance of the CFSP. With the emergence of multiple Brussels-based actors, the increasingly relevant question is whether centralization and delegation affect the outcomes of EU foreign policy. Intensive transgovernmentalism (Wallace \& Reh, 2015, pp. 109-111) seems a particularly suitable description of the mode of governance in the CFSP. Decisions remain in the hand of the member states, but their continuous interactions affect the attitudes and identities of national diplomats. The EU institutions also increasingly have some autonomy in the formulation and implementation of foreign policy.

This article is far from exhaustive, but it raises a couple of reflections on the state of the art of CFSP research. First, it is impossible to analyze the CFSP through one overall concept or approach. The three themes identified in this article all have their own subquestions and research agendas. CFSP research is very rich, and the pluralism in the research agenda should be seen mostly as a strength rather than as a weakness. The drawback is that for students of EU foreign policy, it is becoming nearly impossible to follow all the debates in their entirety. This has resulted in a certain degree of fragmentation.

Second, CFSP scholars make extensive use of concepts and perspectives originating outside their discipline: the research agendas on Europeanization and CFSP governance are two examples. The fact that scholars are open to insights from not only EU studies and international relations but also comparative politics, public administration, economics, and sociology is a healthy sign. Having said that, it remains difficult to find the right balance between uniqueness of EU foreign policy, on the one hand, and using concepts and insights of other disciplines, on the other hand. When it works out, it undeniably adds to our understanding of the CFSP. But in some cases, transferring concepts across disciplines causes more problems than it solves.

Third, we see a scholarly debate that has been very responsive to developments triggered by the changing European and international context. The historiography of the CFSP is almost a function of world politics. From Civilian Power Europe during détente in the 1970s to Normative Power Europe in the midst of transatlantic conflict over Iraq in 2002-2003, it is difficult to deny a certain tide in the CFSP scholarship. This trend continues to date. As a result of the prominence of the emerging powers, various scholars are now interested in EUAsia relations. The withdrawal of the United Kingdom from the EU will undoubtedly affect the 
scholarship on the CFSP. The three research topics identified in this article-actorness, the relation with national foreign policy, and governance-are, however, likely anchors for CFSP research in the years to come.

\section{References}

Adler-Nissen, R. (2014). Symbolic power in European diplomacy: The struggle between national foreign services and the EU's External Action Service. Review of International Studies, 40(4), 657-681.

Aggestam, L. (Ed.). (2008). Ethical power Europe? [Special Issue]. International Affairs, 84(1).

Alecu de Flers, N., \& Müller, P. (2013). Dimensions and mechanisms of the Europeanization of member state foreign policy: State of the art and new research avenues. Journal of European Integration, 34(1), 19-35.

Allen, D. (1998). "Who speaks for Europe?": The search for an effective and coherent external policy. In J. Peterson \& H. Sjursen (Eds.), A common foreign policy for Europe? (pp. 41-58). London: Routledge.

Allen, D., \& Smith, M. (1990). Western Europe's presence in the contemporary international arena. Review of International Studies, 16(1), 19-37.

Balfour, R., \& Raik, K. (2013). Equipping the European Union for the 21st century: National diplomacies, the European External Action Service and the making of EU foreign policy. Helsinki: Finnish Institute of International Affairs.

Batora, J., \& Spence, D. (Eds). (2015). The European External Action Service: European diplomacy post-Westphalia. Basingstoke, U.K.: Palgrave Macmillan.

Bauer, M. \& Trondal, J. (Eds). (2015). The Palgrave handbook of the European administrative system. Basingstoke, U.K.: Palgrave Macmillan.

Bickerton, C. (2011). European Union foreign policy. From effectiveness to functionality, Basingstoke, U.K.: Palgrave Macmillan.

Bickerton, C., Hodson, D., \& Puetter, U. (2015). The New intergovernmentalism: European integration in the post-Maastricht era. Journal of Common Market Studies, 53(4), 703-722.

Bull, H. (1982). Civilian power Europe: A contradiction in terms? Journal of Common Market Studies, 21(2), 149-164.

Burgess, M. (2009). Federalism. In A. Wiener \& T. Diez (Eds.), European integration theory (pp. 25-44). Oxford: Oxford University Press.

Cross, M. (2011). Security integration in Europe: How knowledge-based networks are transforming the European Union. Ann Arbor: University of Michigan Press.

da Conceição-Heldt, E., \& Meunier, S. (Eds.). (2014). Speaking with a single voice: The EU as an effective actor in global governance? Journal of European Public Policy, 21(7).

Damro, S. (2012). Market power Europe. Journal of European Public Policy, 19(5), 682-699. 
Dijkstra, H. (2011). EU external representation in conflict resolution: When does the presidency or the High Representative speak for Europe? European Integration Online Papers, 15(1), 1-23.

Dijkstra, H. (2013). Policy-making in EU security and defense: An institutional perspective. Basingstoke, U.K.: Palgrave Macmillan.

Dijkstra, H. (2014). Approaches to delegation in EU Foreign Policy: The case of the commission. In M. Wilga \& I. Karolewski (Eds.), New approaches to EU foreign policy (pp. 38-55). London: Routledge.

Duchêne, F. (1973). The European Community and the uncertainties of interdependence. In M. Kohnstamm \& W. Hager (Eds.), A nation writ large? Foreign policy problems before the European Community (pp. 1-21). Basingstoke, U.K.: Macmillan.

Duke, S. (2016). The Common Security and Defence Policy. Oxford Research Encyclopedia of Politics.

Duke, S., \& Vanhoonacker, S. (2006). Administrative governance in the CFSP: Development and practice. European Foreign Affairs Review, 11(2), 163-182.

European External Action Service. (2016). EU global strategy. Retrieved from http:// eeas.europa.eu/top_stories/pdf/eugs_review_web.pdf_<http://eeas.europa.eu/top_stories/pdf/ eugs review web.pdf>.

Featherstone, K., \& Radaelli, C. (Eds.). (2003). The politics of Europeanization. Oxford: Oxford University Press.

Gebhard, C. (2011). Coherence. In C. Hill \& M. Smith (Eds.), International relations and the European Union (pp. 101-127). Oxford: Oxford University Press.

Ginsberg, R. (1989). Foreign policy actions of the European Community: the politics of scale. Boulder, CO: Lynne Rienner.

Henökl, T., \& Trondal, J. (2015). Unveiling the anatomy of autonomy: Dissecting actor-level independence in the European External Action Service. Journal of European Public Policy, 22(10), 1426-1447.

Hill, C., \& Smith, M. (Eds.). (2011). International relations and the European Union (2d ed.). Oxford: Oxford University Press.

Hill, C., \& Wong, R. (2011). Many actors, one path? The meaning of Europeanization in the context of foreign policy. In R. Wong \& C. Hill (Eds.), National and European foreign policies. Towards Europeanization (pp. 210-232). London: Routledge.

Hix, S. (1994). The study of the European Community: The challenge to comparative politics. West European Politics, 17(1), 1-30.

Hoffmann, S. (1966). Obstinate or obsolete? The fate of the nation-state and the case of Western Europe. Daedalus, 95(3), 862-915.

Hyde-Price, A. (2006). “Normative” power Europe: A realist critique. Journal of European Public Policy, 13(2), 217-234. 
Jørgensen, K., Aarstad, A., Drieskens, E., Laatikainen, K., \& Tonra, B. (Eds). (2015). SAGE handbook on European foreign policy. Thousand Oaks, CA: SAGE.

Juncos, A., \& Pomorska, K. (2011). Invisible and unaccountable? National Representatives and Council Officials in EU foreign policy. Journal of European Public Policy, 18(8), 1096-1114.

Jupille, J., \& Caporaso, J. (1998). States, agency and rules: The European Union in global environmental politics. In C. Rhodes (Ed.), The European Union in the world community (pp. 213-229). Boulder, CO: Lynne Rienner.

Kavalski, E. (2013). The struggle for recognition of normative powers: Normative Power Europe and normative power China in context. Cooperation and Conflict, 48(2), 247-267.

Keukeleire, S. (2003). The European Union as a diplomatic actor: Internal, traditional and structural diplomacy. Diplomacy and Statecraft, 14(3), 31-56.

Keukeleire, S., \& Delreux, T. (2014). The foreign policy of the European Union (2d ed.). Basingstoke, U.K.: Palgrave.

Manners, I. (2002). Normative power Europe: A contradiction in terms? Journal of Common Market Studies, 40(2), 235-258.

Manners, I., \& Whitman, R. (Eds.). (2000). The foreign policies of European Union member states. Manchester: Manchester University Press.

Müller-Brandeck-Bocquet, G., \& Rüger, C. (Eds.). (2011). The High Representative for the EU foreign and security policy—review and prospects. Baden-Baden, Germany: Nomos Verlag.

Musu, C. (2003). European foreign policy: A collective policy or a policy of "converging parallels"? European Foreign Affairs Review, 8(1), 35-49.

Nicolaïdis, K., \& Whitman, R. (Eds.). (2013). Normative power Europe [Special issue]. Cooperation and Conflict, 48(2).

Norman, P. (2003). The accidental constitution. The story of the European Convention. Brussels: EuroComment.

Nuttall, S. (1992). European political co-operation. Oxford: Clarendon Press.

Nuttall, S. (2000). European foreign policy. Oxford: Oxford University Press.

Pomorska, K. (2007). The impact of enlargement: Europeanisation of Polish Foreign Policy? Tracking adaptation and change in Polish Ministry of Foreign Affairs. The Hague Journal of Diplomacy, 2(1), 25-51.

Sjöstedt, G. (1977). The external role of the European Community. Farnborough, U.K.: Saxon House.

Sjursen, H. (2006). The EU as "normative" Power: How can this be? Journal of European Public Policy, 13(2), 235-251.

Smith, K. (2014). European Union foreign policy in a changing world. London: Polity Press. 
Smith, M. E. (2004). Europe's foreign and security policy: The institutionalization of cooperation. Cambridge, U.K.: Cambridge University Press.

Smith, M., Keukeleire, S., \& Vanhoonacker, S. (Eds.). (2016). The diplomatic system of the European Union: Evolution, change and challenges. London: Routledge.

Spence, D. (2016). The European Commission's External Service. In M. Smith, S. Keukeleire, \& S. Vanhoonacker (Eds.), The diplomatic system of the European Union: Evolution, change and challenges (pp. 29-45). London: Routledge.

Tonra, B. (2001). The Europeanisation of national foreign policy: Dutch, Danish and Irish foreign policy in the European Union. Aldershot, U.K.: Ashgate.

Vanhoonacker, S., \& Pomorska, K. (2013). The European External Action Service and agendasetting in European foreign policy. Journal of European Public Policy, 20(9), 1316-1331.

Vink, M., \& Graziano, P. (2006). Challenges of a new research agenda. In P. Graziano \& M. Vink (Eds.), Europeanization: New research agendas (pp. 3-22). Basingstoke, U.K.: Palgrave Macmillan.

Wagner, W. (2003). Why the EU's common foreign and security policy will remain intergovernmental: A rationalist institutionalist choice analysis of European crisis management policy. Journal of European Public Policy, 10(1), 160-194.

Wallace, H., \& Reh, C. (2015). An institutional anatomy and five policy modes. In H. Wallace, M. Pollack, \& A. Young (Eds.), Policy-making in the European Union (7th ed., pp. 72-112). Oxford: Oxford University Press.

Waltz, K. (1979). Theory of international politics. Reading, MA: Addison-Wesley.

Wong, R. (2011). The Europeanization of foreign policy. In C. Hill \& M. Smith (Eds.), International relations and the European Union (2d ed., pp. 149-170.) Oxford: Oxford University Press.

Wong, R., \& Hill, C. (Eds.). (2011). National and European Foreign Policies: Towards Europeanization. London: Routledge.

\section{Notes}

1. The High Representative of the Union for Foreign Affairs and Security Policy is also a vice president of the European Commission. While HR/VP is regularly used, this article refrains from using too many acronyms.

\section{Related Articles}

International Security: Nuclear Proliferation

Federalism as a Theory of Regional Integration

The Founding Treaties of the European Union and Their Reform 
The Common Security and Defense Policy

Austria and the European Union

Page 17 of 17

Printed from Oxford Research Encyclopedias, Politics. Under the terms of the licence agreement, an individual user may print out a single article for personal use (for details see Privacy Policy and Legal Notice).

date: 31 January 2021 